\title{
POLLITITKK
}

\section{Militæraktivisme brandet som fredsaktivisme? Norges kampanje for en plass i FNs sikkerhetsråd}

\author{
Sigrun Marie Moss og Malcolm Langford \\ Universitetet $i$ Oslo, Norge
}

\begin{abstract}
Sammendrag
Hvordan håndterer Norge sin militæraktivisme og sitt NATO-medlemskap når landet vil presentere seg selv som en fredsnasjon? Problemstillingen ble aktuell i det norske utenriksdepartementets nylige kampanje for å få Norge valgt inn i FNs sikkerhetsråd, hvor ideen om Norge som fredsnasjon stod sentralt. I denne artikkelen bruker vi nasjonsbranding som et analytisk rammeverk for å forstå hvordan Norge bygget opp sin kampanje som fredsnasjon og håndterte det konkurrerende narrativet om sin rolle i krig. Som et sekundærfokus ser vi også på hvordan Norges to konkurrenter, Irland og Canada, fremstilte seg på disse to dimensjonene - som er av særinteresse da Irland ikke er NATO-medlem. For å utforske disse spørsmålene analyserer vi taler og tekster fra det norske diplomatiet og regjeringen vedrørende kampanjen, samt ser på kampanjematerialet til de tre landene. Gitt at de tre landenes profil er påfallende lik, fant vi at alle måtte forsøke å finne en måte å brande seg på som uttrykket ens særtrekk og høynet ens relevans i sammenligning med de to andre landene. I analysen av Norge ser vi at militæraktivisme stadig ble hvisket ut i løpet av den norske kampanjen og at andre tematikker ble brukt i brandingen - som for eksempel likestilling og bidrag til internasjonal utvikling. Dette skulle dermed skulle legitimere ideen om fredsnasjonen Norge, et land som alle andre kan stole på.
\end{abstract}

Nøkkelord: Sikkerhetsrådet • kampanje • nasjonsbranding • fredsaktivisme • militæraktivisme

\footnotetext{
^Kontaktinformasjon: Sigrun Marie Moss, e-post: s.m.moss@psykologi.uio.no

(C2020 Sigrun Marie Moss og Malcolm Langford. This is an Open Access article distributed under the terms of the Creative Commons Attribution 4.0 International License (http://creativecommons.org/licenses/by/4.0/), allowing third parties to copy and redistribute the material in any medium or format and to remix, transform, and build upon the material for any purpose, even commercially, provided the original work is properly cited and states its license.

Citation: Moss, S. M. E) Langford, M. (2020). Militeraktivisme brandet som fredsaktivisme? Norges kampanje for en plass $i$ FNs sikkerhetsråd. Internasjonal Politikk, 78(3), 397-410. http://dx.doi.org/10.23865/intpol.v78.2557
} 
I 2004 sa daværende statsminister Bondevik: «Norge er en fredsnasjon». Dette understreket også Støre som utenriksminister i 2006: «Norge er en nasjon som ønsker fred». Forestillingen om Norge som en fredsnasjon har stått sentralt siden 1890-årene (Leira, 2013; se også Skånland, 2010; Stokke, 2010, 2012). I det norske utenriksdepartementets kampanje for å få Norge valgt inn i FNs sikkerhetsråd (heretter SR) for perioden 2021-2022, stod ideen om Norge som fredsnasjon og Norges fredsaktivisme sentralt. I kampanjebrosjyren er Norges militæraktivisme paradoksalt nok også vektlagt, med fokus på fredsbevarende operasjoner og kvinnelig deltagelse. Kampanjematerialet refererer til 40000 nordmenns deltakelse i FN fredsbevarende operasjoner siden 1949, og viser et bilde av norske Kristi Lund, den første kvinnelige styrkesjef $\mathrm{i}$ en fredsbevarende FN-operasjon. Selv om fredsaktivisme og militæraktivisme ikke trenger å være klare, binære motsatser, så kan kontrasten her invitere til et nærmere blikk på hvordan disse aspektene ved det norske kandidaturet ble presentert. Aktivisme forstås her som nasjonens villighet til å ta initiativ på tross av kostnader (Branner, 2013).

I juni 2020 stod valget om setene i SR. Norge fikk ett av to i sin gruppe, og starter sitt kandidatur i januar 2021. Men fremføringen av masternarrativet i Norges kampanje, om Norge som fredsnasjon, var komplisert. ${ }^{1}$ For det første er Norges medlemskap i NATO og militærdeltakelse i en rekke ikke-FN-operasjoner, blant annet Afghanistan, Irak og Libya, noe vanskelig å forene med masternarrativet. For det andre kompliseres bildet av Norge som fredsnasjon av konkurrentene i kampen om de to tilgjengelige SR-setene for gruppen «Vestlige europeere og andre». Norge konkurrerte med Irland og Canada. Irland er ikke NATO-medlem. Begge lands innsats på fredsbygging og likestilling i forsvaret kompliserte ytterlige oppbyggingen av narrativet om Norge som en unik fredsnasjon (Langford, 2018). En nasjonsbranding i kampanjesammenheng må ses opp mot situasjon samt konkurrenter, da det påvirker hvordan nasjonen differensierer seg.

I denne artikkelen går vi tilbake til kampanjen, og spør: Hvordan fremstilte Norge seg i sin kampanje som fredsnasjon, og hvordan ble militæraktivismen håndtert? Som et sekundærfokus ser vi også i et komparativ lys på hvordan Irland og Canada fremstilte seg på disse to dimensjonene i sine kampanjer.

For å utforske disse to spørsmålene analyserer vi taler og tekster fra det norske diplomatiet og regjeringen vedrørende kampanjen, samt ser på kampanjematerialet til de tre landene. Dette muliggjør en analyse av hvorvidt og hvordan militæraktivisme normaliseres i kampanjen; hvorvidt dette brandes under fanen av fredsnasjonen Norge, og hvilken rolle NATO som institusjon spiller. Ut fra dette vil vi dermed bidra til diskusjonen av bruken av fredsfokuserte og militærfokuserte narrativer i norsk utenriks- og sikkerhetspolitikk, slik disse fremkommer i kampanjesammenheng.

\footnotetext{
${ }^{1}$ Norge har hatt sete i sikkerhetsrådet fire ganger (1949-1950; 1963-1964; 1979-1980; 2001-2002).
} 


\section{Masternarrativer og nasjonsbranding}

I kampanjen skulle landene overtale andre land til å stemme på seg, ved å nettopp fremme sitt eget land som positivt unikt. For å analysere dette lener vi oss på rammeverkene om masternarrativer og nasjonsbranding. Sammen handler disse om narrativene i samfunnet om hvem «vi-et» er, og hvordan slike karakteristikker benyttes for å fremme nasjonens brand. I konkurransen om setet i SR er et slikt nasjonalt brand vesentlig.

I samfunn har man masternarrativer om hvem man er (Hammack, 2008), som, når det kommer til sosial kategorisering, tjener en politisk, kollektiv interesse. Et slikt masternarrativ representerer en kollektiv historie gruppen ser som grunnleggende (Hammack, 2011). Disse masternarrativene finnes på alle nivåer av sosial kategorisering (som kjønn, klasse og nasjonalitet), og hviler på en essensialistisk doktrine om disse kategoriene. Dette, ifølge Reicher og Hopkins (2001), gir disse kategoriene en naturgitt heller enn sosial karakter. Samtidig vil det finnes opponerende narrativer og motstand mot sterke masternarrativer i samfunnet (Hammack, 2011). Masterarrativene er kontekstuelle, og varierer med tid, da disse konstitueres av en blanding av ideer, bilder og forestillinger. Som Castoriadis (1975, s. 465) skriver, «the imaginary of the society [...] creates for each historical period its singular way of living, seeing and making its own existence».

Masternarrativer er ofte rettet mot oppbygging av et selvbilde, og inngår i skapingen av en personlig eller nasjonal identitet. Mest vesentlig for vår artikkel er masternarrativet som knytter det norske selvbildet til fredsbygging (Skånland, 2009, 2010; se også Schouenborg, 2013). Forestillingen om Norge som fredsnasjon er ifølge Leira (2013, s. 339) forbundet med nasjonal identitet: «Norge og nordmenn har engasjert seg $\mathrm{i}$ fredspromotering først og fremst fordi det har blitt forstått som del av det som gjør 'oss' norske» (vår oversettelse), med «læresetninger» som Nordal Griegs «Krig er forakt for liv, fred er å skape».

Rollen til masternarrativer i en internasjonal konkurranse kan forstås bedre gjennom bruk av nasjonbranding som analytisk kategori (Langford \& Larsen, 2018). Branding knyttes ofte til organisasjoner og produkter, men siden tidlig 2000-tall har det også i økende grad blitt vanlig å snakke om og arbeide aktivt med branding av nasjoner (se f.eks. Angell \& Mordhorst, 2015). Dinnie (2008, s. 15) beskriver en nasjon sitt brand som "the unique, multi-dimensional blend of elements that provides the nation with culturally grounded differentiation and relevance for all of its target audiences». Landene vil skape et enkelt, solid og stabilt bilde som differensierer dem fra andre, og om de lykkes, vil de dermed inneha alle ingredienser til et vellykket nasjonsbrand (Browning, 2007). Målet kan være økt investering, turisme, politisk seier, innflytelse eller også oppbygging, eller forsterkning av nasjonalidentitet og eksistensiell mening. Ifølge Aaker (2003, s. 83) er «differensiering brand-togets motor» (vår oversettelse). En nasjon sitt brand eksisterer med eller uten bevisste strategier (Fan, 2006) men vellykket nasjonsbranding kan bistå i å forbedre brandet. 
Et nasjonsbrand er ofte snakket om for et ytre publikum. Hvilket bilde man skal fremme av Norge til et eksternt publikum, kan være et annet narrativ enn det man fokuserer på internt, og det kan variere med resultatet man ønsker seg. I fremstillingen av Norge som en fredsnasjon, kan det være eksempler på at Norge har ønsket å tone ned egen innsats i fredsprosesser, nettopp for at narrativet skal være om landet som fredsprosessen omhandler heller enn en aktiv branding av Norge. Det vil også avhenge av publikum. Branding man inngår i for å fremme Norge som turistdestinasjon, vil være ulik den man fremmer når det gjelder å få et sete i sikkerhetsrådet.

Håndteringen av slike nasjonale brander og aktiv nasjonsbranding er hyppig sett i sammenheng med offentlig diplomati (Van Ham, 2001, 2008). Dette giør ofte utenriksdepartementer sentrale, noe som også er tilfelle i Norge (Angell \& Mordhorst, 2015). Vellykkete brandingstrategier trekker også inn andre støttespillere, som journalister, frivillige organisasjoner, akademikere og andre land. Det skaper oppfattelse av et naturlig og bredt forankret - fremfor et konstruert og subsidiert - bilde.

Samtidig er nasjonbranding komplisert. Fan (2006, s. 12) understreker at det er svært mange faktorer som inngår i slike bilder av et land: «Nasjonsbranding vedrører et lands helhetlige bilde, som dekker politiske, økonomiske, historiske og kulturelle dimensjoner» (se også Angell \& Mordhorst, 2015). Dette helhetlige bildet vil også måtte relatere seg til masternarrativene diskutert over. Det gis muligheter til dette i spesifikke brandingkampanjer, der for eksempel likestilling kjennetegner nesten alle norske brandingstrategier (Danielsen, Larsen \& Owesen, 2014; Larsen, Moss \& Skjelsbæk, 2021). Samtidig kan nasjonsbrandet skape utfordringer. Diskrepansen mellom «bildet» og «realiteten» må ikke bli for stor - og et slikt eventuelt avvik må håndteres godt, med tanke på brand og omdømme (Browning, 2007; Mordhorst, 2015).

En særutfordring for Norges branding er diskrepansen mellom den norske fredsnasjonen og militæraktivismen, med spenninger mellom disse to versjonene av hva det norske er. På den ene siden kan Norge lene seg på spesifikke FNmilitære bidrag, der det har blitt argumentert at spenningen mellom masternarrativet om Norge som fredsnasjon og den militære komponenten er mindre. Leira (2013, s. 348) sier:

Norge var også en veldig sterk støttespiller for FN fra begynnelsen, og hadde en sterk tilstedeværelse i fredsbevarende operasjoner fra starten av slike operasjoner. Slik deltakelse ble forstått i relasjon til fred og internasjonalisme, heller enn forsvar, som vist ved holdningen innad i det norske militæret, der FN-operasjoner i beste fall var en karrierere-blindvei og i verste fall var bortkastede ressurser. (Græger \& Leira, 2005, vår oversettelse)

På den andre siden har vi en uenighet som har vært tilstedeværende i norsk militært engasjement lenge, og som kanskje er mer fremtredende i ikke-FN oppdrag. Haaland (2007, s. 505) forklarer: «mange norske politikere foretrekker enda å understreke de ikke-militære aspektene av Norges deltakelse i internasjonale konfliktsituasjoner og 
de humanitære aspektene av deres militære bidrag» (vår oversettelse). Haaland refererer til 2003-eksemplet hvor Norge sendte et ingeniørkompani til Irak, der regjeringen understreket av dette var et humanitært bidrag som skulle hjelpe irakere med å gienreise sitt land. Dette førte til negative reaksjoner hjemme - fra politisk opposisjon, bistandsorganisasjoner så vel som internt i militæret selv, der dette ble oppfattet som en tildekking av militær tilstedeværelse i Irak som ikke-militær (Dagbladet, 2003; Thomassen, 2003; se også Harpviken, 2011). Om Afghanistan skriver Matlary (2009) at krigen, sikkerhetspolitikken og den militære aktivismen ble fordekket av verdier som fred og nasjonsbygging. Denne bruken av fredsdimensjonen over militærdimensjonen knytter Matlary til en omskriving av det militære, portrettert med fokus på myke verdier.

Denne motivasjonen til å brande Norge som humanitærnasjon først og fremst, kom også frem i analyser av involvering i Libya (da sammen med NATO) beskrevet av Dicke, Anson, Roughton, og Hendrickson, (2013, s. 41): «Norge har investert omfattende innsats $i$ å fremstille seg som en humanitær persona på den internasjonale scene, og var veldig klar på at Qaddafi regimets menneskerettighetsbrudd var en av hovedårsakene for deres deltakelse i Libya oppdraget» (Dicke, Anson, Roughton \& Hendrickson, 2013, s. 41, vår oversettelse). Denne spenningen har gjort seg gjeldende ved flere anledninger. I 2009 utga Edström, Lunde og Matlary boka Krigerkultur $i$ en fredsnasjon, som belyser en fremvoksende krigerkultur i forsvaret, $\mathrm{i}$ tråd med profesjonaliseringen av dette, opp mot nasjonens eget bilde av Norge som fredsnasjon (se også Rones, 2015).Vi argumenterer i denne artikkelen for at diskrepansen mellom fredsnasjonen Norge og militæraktivismen også kommer til uttrykk i kampanjen for setet i SR.

\section{Metode}

Teksten vår baserer seg på analyser av to typer data. Det ene er kampanjebrosjyrene for Norge, Irland og Canada. Disse ligger tilgjengelig på hvert land sine nettsider. I kampanjematerialet utkrystalliseres kjernepunktene som hvert land ønsker å fremme. Disse er svært ulike på flere punkter (Norges er på fire, små sider; Canada sin er på 20 store sider, mens Irland sin er på 10 sider). Norges er mest uformell, da den inneholder både triviell informasjon (som antall par ski i Norge; hvilken FIFA-rangering norsk fotball har), side om side med svært relevant informasjon (som Norges engasjement i FN, størrelse på utviklingshjelp osv.). De to andre kampanjene legger i stor grad kun vekt på relevant informasjon. Allikevel er det også mange likhetstegn mellom kampanjene, både i innhold som dekkes, og hvordan poeng fremstilles. Vi analyserte brosjyrene for henholdsvis militærrelatert og fredsrelatert innhold.

Videre har vi analysert taler og tekster med direkte relevans for Norges sikkerhetsrådskampanje. Her har vi via regjeringens nettsider søkt på "sikkerhetsrådet», og lett frem de sakene som $\mathrm{i}$ tittelen og kort ingress er direkte relatert til sikkerhetsrådskampanjen. I 2018 er 72 saker relatert til sikkerhetsrådet, hvorav 10 ble vurdert 
som særlig relevant for vår diskusjon. I 2019 var det 64 saker, hvor 5 ble vurdert som ekstra relevante. Per april 2020 var det 23 saker, hvorav 3 saker ble vurdert som ekstra relevante. Vi var ute etter sakene der kandidaturet var i hovedfokus, og hvor kampanjens kjerne, eller direkte referanser til militære/fredsbevarende operasjoner eller fred var nevnt. Vi gjennomgikk de relevante sakene, og analyserte utdragene som handlet om disse fokusområdene. Her var vi ute etter hvilke narrativer som ble brukt, og hvilken posisjon det militærrelaterte og det fredsrelaterte ble gitt. Under gjengir vi utdrag av utvalgte tekster. Disse utvalgte tekstene adresserer ulike publikum, fra nasjonalt publikum til det relevante FN-publikum, noe som påvirker både budskap og vektlegging. Vi tar først for oss den norske kampanjen, og ser deretter på Irland og Canada.

\section{Norges kampanje}

Den norske kampanjen for en plass i SR begynte lenge før valget. De nordiske landene rullerer uformelt valgene så de ikke konkurrer mot hverandre - og Sverige fikk en plass i siste runde. Derfor var planen for Norges kandidatur 2021-2022 klar tidlig, samtidig som Norge har prøvd å unngå kritikk for stor ressursbruk, som de fikk på hjemmebane ved sist kampanje. ${ }^{2}$

Kampanjebrosjyren er kanskje den mest «offisielle» kilden til Norges kampanje det er her kjernepunktene er utkrystallisert. Slagordet er "Consistent partner. Common future». Brosjyren Norway for the UN Security Council 2021-2022 $2^{3}$ består av 32 ulike punkter, med alt fra prosent av GNI brukt på utviklingshjelp, til antall øyer i Norge og FIFA-rangering. Av de 32 punktene, er fire spesifikt militærrelaterte:

\begin{tabular}{|c|c|c|}
\hline & Relatert til & Militærrelatert tekst i Norges kampanjebrosjyre for SR \\
\hline 1 & Militæret og kjønn & $\begin{array}{l}\text { «Gender equality in the armed forces - } 2015 \text { - introducing universal } \\
\text { conscription» }\end{array}$ \\
\hline 2 & $\begin{array}{l}\text { FN-fredsoperasjoner } \\
\text { og kjønn }\end{array}$ & $\begin{array}{l}\text { «Major General Kristin Lund is the first female Force Commander in a } \\
\text { United Nations peacekeeping operation.» }\end{array}$ \\
\hline 3 & FN-fredsoperasjoner I & $\begin{array}{l}\text { "More than } 40000 \text { Norwegians have served in UN-led peace operations } \\
\text { since 1949, including currently in South Sudan, the Middle East and Mali.» }\end{array}$ \\
\hline 4 & FN-fredsoperasjoner II & $\begin{array}{l}\text { «More than } 40000 \text { Norwegian women and men have served in UN peace } \\
\text { operations as military and police personnel since 1949» }\end{array}$ \\
\hline
\end{tabular}

\footnotetext{
${ }^{2}$ Norge skrytet at de bruke mindre penger enn konkurrentene, men summene var fortsatt betydelige. Norge hadde et dedikert kampanjeteam og kommunikasjonsbudsjett, økte midler til Norges FN-delegasjon og reisevirksomhet, samt innkjøp av ny residens til Norges FN-ambassadør, som til dels begrunnes i Norges SR-kampanje (Skjæraasen, 2018).

${ }^{3}$ Brosjyre, Norway for the UNSC 2012-2022: https://www.regjeringen.no/globalassets/departementene/ud/vedlegg/fn/flyer_un.pdf
} 
To av punktene $(1$ og 2$)$ handler om likestilling. I punkt 4 giøres det et poeng ut av at styrkene man sender i FN fredsbevarende oppdrag inkluderer både kvinner og menn. Det er dermed kun det tredje punktet som ikke knytter norsk likestilling til det militære. Videre kan man lure på hvorfor man blant 32 punkter har valgt å inkludere punkt tre og punkt fire, som er nær overlappende.

I brosjyren er det videre 10 illustrasjoner. I tillegg til bilder av Trygve Lie og major generel Kristin Lund, er det også inkludert et bilde av en skigåer og et kart over Norge. Igjen ser vi understreking av likestillingsbidraget. Flere har argumentert for at Norges prominente rolle som likestillingsforkjemper fikk seg et slag for baugen når det kom til Norges forsvar, med den lave andelen kvinner i forsvaret (Rones \& Fasting, 2017), og data om at de fleste andre NATO-land hadde flere kvinner i sine forsvar enn Norge (Skjelsbæk \& Tryggestad, 2011). Dette passet dårlig med det bildet av Norge man ønsket å fremme, og resulterte i et økt fokus på å få flere kvinner i forsvaret (Forsvarsdepartementet, 2007). Likevel i kampanjebrosjyren passes det på å knytte fredsbevarende operasjoner vel så tett til norske kvinner, som til norske menn.

Om vi ser på fredsrelatert tekst (ekskludert punktene relatert til fredsoperasjoner over), utgjør dette tre spesifikke punkter (disse kommer i tillegg til diverse punkter om humanitarisme):

\begin{tabular}{|c|c|c|}
\hline & Relatert til & Fredsrelatert tekst i Norges kampanjebrosjyre for SR \\
\hline 1 & Fredsprosesser & $\begin{array}{l}\text { «Norway seeks to establish trust, listen to all sides and engage in peace } \\
\text { and reconciliation processes, whether in Colombia, Israel-Palestine, South } \\
\text { Sudan, or the Philippines» }\end{array}$ \\
\hline 2 & Fred og sikkerhet & $\begin{array}{l}\text { «Norway has a long history of solidarity and partnerships for sustainable } \\
\text { development, peace and security, and human rights» }\end{array}$ \\
\hline 3 & $\begin{array}{l}\text { Kvinner, fred og } \\
\text { sikkerhet }\end{array}$ & $\begin{array}{l}\text { «Norway promotes women's rights and participation at all levels of society, } \\
\text { including through persistent efforts for women, peace and security» }\end{array}$ \\
\hline
\end{tabular}

Her understrekes nøytralitet og pålitelighet, lang erfaring og praksis, samt fokus på likestilling og kvinner.

I kampanjebrosjyren understrekes dermed både det militære og det fredsrelaterte. Dette finner vi ikke igjen i talene eller tekstene relatert til kampanjen. Utenriksminister Søreide lanserte Norges kandidatur 22. juni 2018. I talen hun holdt i New York fokuserte hun på fredsnasjonen Norge, og utelot det militære:

Our support is consistent. Across the Norwegian political spectrum, there is broad support for the UN and our engagement for sustainable development and peace. [...] We will bring to the Council our experience from peace and reconciliation processes - in Africa, the Middle East, the Philippines and Colombia. As women's rights and participation is a prerequisite for lasting peace and stability, we will keep it high on our agenda. (Utenriksdepartementet, 2018) 
Denne talen er gitt til et internasjonalt publikum, og det er bare multilateral, erfaringsbasert kunnskap og praksis og likestillingselementer som fremheves. Det samme går igjen i mange andre tekster, inkludert i teksten publisert på regjeringens nettsider samme dato, med tittelen "Hvorfor ønsker Norge å bli valgt inn i Sikkerhetsrådet?» (Utenriksdepartementet, 2020) i teksten «Norge søker plass i FNs sikkerhetsråd i 2021-2022» fra dagen før (Utenriksdepartementet, 2018a), i debattinnlegget statssekretær Audun Halvorsen hadde iVG i juni 2019 (Halvorsen, 2019), og i talen som statssekretær Jens Frælich Holte holdt ved en Civita-frokost i mars 2019 (Utenriksdepartementet, 2019). Det er ikke fokus på det militære, men stort fokus på Norge som fredsnasjon. I Holtes tale er det også interessent til å se konstrueringen av sikkerhet:

It is certainly the case that most conflicts on the Security Council's agenda take place pretty far from Norway. The agenda of the Council is dominated by conflicts in Africa and the Middle East. This, however, by no means imply that the Security Council is less relevant to Norway [...]

Even if conflicts are far away geographically, they will affect our security and economy. In 2013, when our government took office, we did not know that we would experience conflict in our immediate neighbourhood. The example of Ukraine shows that security issues also arises close to home.

Countries like Norway should be present around the table when binding decisions on war and peace are being made [...] Critical issues are at stake, also for us, and we cannot simply leave these decisions to others.

Her blir sikkerhetsproblematikk knyttet til setets verdi og relevansen for Norge, men igjen uten at det militære får fokus. Det bygges opp et bilde av Norge på sidelinjen, men med interesse av å løse problemene. Talene her har ulike publikum, med Søreides første tale som relevant for et internasjonalt publikum, mens de resterende er mer myntet på et nasjonalt publikum. At alle talene har til felles at det ikke fokuseres på militæraktivismen spesifikt, er verdt å merke seg. Fremhevelsen av det militære i den norske kampanjebrosjyren for SR, men unnlatelsen av å ta opp dette eksplisitt i kampanjerelaterte taler, kan i den norske kampanjen potensielt forklares med at militæraktivismen knyttet til FN-operasjoner ses på som innlemmet i fred og internasjonalisme, heller enn at diplomater og politisk ledelse ser dette som militært i den mer vanlige forstand. Dette kan underbygges av Karlsrud og Oslands (2016, s. 784-785) differensiering mellom norske FN-bidrag og NATO-bidrag:

Norway's contributions to UN peacekeeping operations are generally perceived as value-driven, motivated by solidarity. In contrast, participation in NATO operations has always been understood as more self-interested, maintaining transatlantic relations to ensure the security guarantee of the Alliance.

Samtidig kan man stille spørsmålstegn ved om ikke norske regjeringer har satt for stort likhetstegn mellom fredspolitikk og sikkerhetspolitikk, og at spenningene mellom disse bør anerkjennes (se Harpviken \& Skjelsbæk, 2010, i relasjon til Afghanistan-deltakelsen til norske militære). 
En alternativ forklaring er at Norge har mindre å vinne på å fremme det militære aspektet. Som vi skal se, kan Irland og Canada matche Norge på både fredsbevarende operasjoner og likestilling i forsvaret. Dessuten handler en god del av SR-kampanjen om å sanke stemmer blant de 70-pluss stater i Afrika og Stillehavet som kan være skeptiske til og mindre interessert i militæraktivisme (selv fredsbevarende operasjoner kan bli regnet som en form for kolonialisme). Et kjennetegn i mange uttalelser fra Norge, er bidrag til internasjonal utvikling, pålitelighet og nøytralitet.

\section{Irland og Canadas kampanjebrosjyrer}

Som et sekundært fokus i denne artikkelen, vender vi oss til Irland og Canada, og ser på hvordan de fremstilte seg i sine kampanjebrosjyrer på det militærrelaterte og det fredsrelaterte.

Irland har en 10-siders brosjyre om sitt kandidatur, ${ }^{4}$ med slagordet: «Empathy, partnership, independence». Tre punkter i brosjyren er militærrelaterte:

\begin{tabular}{lll}
\hline Relatert til & Militærrelatert tekst i Irlands kampanjebrosjyre for SR \\
\hline 1 & FN-fredsoperasjoner & $\begin{array}{l}\text { «Since 1958 we have been a UN peacekeeping nation. In that period, } \\
\text { not one month has passed without Irish troops participating in UN } \\
\text { peacekeeping operations. Today, Ireland is one of the highest per capita } \\
\text { troop contributors to UN peacekeeping globally.» }\end{array}$ \\
$\begin{array}{ll}\text { FN-fredsoperasjoner } \\
\text { som et fokus i } \\
\text { utenrikspolitikken }\end{array}$ & $\begin{array}{l}\text { "Our foreign policy has a strong tradition of principled engagement on } \\
\text { development, humanitarian assistance, disarmament, human rights and } \\
\text { peacekeeping.» } \\
\text { FN-fredsoperasjoner }\end{array}$ & $\begin{array}{l}\text { "Ireland's participation in UN peacekeeping has been unbroken since 1958. } \\
\text { Today, Ireland is among the highest per capita troop contributors to UN } \\
\text { Peacekeeping Operations» (Fra fototekst) }\end{array}$ \\
&
\end{tabular}

I disse punktene understrekes Irlands vedvarende og sterke innsats i fredsbevarende FN-operasjoner. Teksten i seg selv er ikke kjønnet. Men, i den irske brosjyren er det 5 bilder. Det femte bildet er av to kvinnelige irske FN-soldater. Hun vendt mot kameraet smiler stort til en smilende mor med en leende baby. Her kan vi se paralleller både til fokuset på det militære og likestilling, men også til en humanitær fremstilling av deltakelsen i FNs fredsoperasjoner. Begge disse har altså likheter med fremstillingen i den norske brosjyren.

Mye av teksten i den irske kampanjen er direkte eller indirekte fredsrelatert, med følgende utdrag som de mest spesifikke:

\footnotetext{
${ }^{4}$ Irlands kampanje-brosjyre: https://merrionstreet.ie/MerrionStreet/en/ImageLibrary/20180702.pdf
} 


\begin{tabular}{|c|c|c|}
\hline & Relatert til & Fredsrelatert tekst i Irlands kampanjebrosjyre for SR \\
\hline 1 & Fredsbevaring & $\begin{array}{l}\text { "Yet while we celebrate the end of violence, the lives saved and the futures } \\
\text { transformed, we are reminded daily of the challenges of sustaining peace.» } \\
\text { Michael D. Higgins, President of Ireland }\end{array}$ \\
\hline 2 & $\begin{array}{l}\text { Inkluderende } \\
\text { fredsprosesser }\end{array}$ & $\begin{array}{l}\text { "We have learned through our own history that tackling the root causes of } \\
\text { conflict is required if peace is to be built and sustained. We understand the } \\
\text { importance of listening to the voices of all community members. We know } \\
\text { that peace-building takes time. It must be carefully nourished, involve all } \\
\text { in society: peace cannot simply be imposed from the top. We believe that } \\
\text { women and girls have a special role to play in building peace, with all of the } \\
\text { complexities that job brings.» }\end{array}$ \\
\hline 3 & $\begin{array}{l}\text { Fredsprosesser og } \\
\text { EUmedlemsskap }\end{array}$ & $\begin{array}{l}\text { "As Ireland's national peace process and membership of the European } \\
\text { Union has shown us, we are far stronger acting collectively than we are } \\
\text { acting alone. [...] Partnership and cooperation has brought peace and } \\
\text { prosperity to our island and our region.» }\end{array}$ \\
\hline
\end{tabular}

Her trekkes det frem en tredobbel rolle: Irlands nylige konfliktopplevelser, Irlands rolle som et uavhengig land, og Irland som en mektig fredsbygger. Legitimitet søkes giennom det å selv ha opplevd konflikt nylig. Samtidig kan de stå frem som en uavhengig fredsbygger. På den ene siden løfter Irland indirekte frem sitt ikke-medlemskap i NATO, ved at uavhengighet er nevnt 9 ganger i brosjyren. I Norges brosjyre er uavhengighet ikke nevnt. Irland trekker ikke eksplisitt frem i brosjyren at de er ikke et medlem av NATO, men det er uformelt mye brukt i lobbying (Langford, 2018; Lynch, 2019). På den andre siden nevner Irland EU-medlemskapet, som Norge og Canada ikke kan vise til. Det viser at Irland kan bruke EUs makt og muskler når det gjelder fredsspørsmål, som kan bli nyttig i konfrontasjoner med verdens supermakter USA, Kina og Russland. Som Norge og Canada har opplevd, koster diplomatiske konflikter med Kina mye økonomisk.

Canadas kampanjebrosjyre er på 20 sider, er tilgjengelig på 7 språk, ${ }^{5}$ og har slagordet «Together». Teksten knyttes aktivt til ulike bærekraftsmål. Det militærrelaterte kommer opp flere ganger, hvorav disse er de mest eksplisitte:

\begin{tabular}{|c|c|c|}
\hline & Relatert til & Militærrelatert tekst i Canadas kampanjebrosjyre for SR \\
\hline 1 & FN-fredsoperasjoner & $\begin{array}{l}\text { "Lester B. Pearson, former prime minister of Canada, was awarded the } \\
\text { Nobel peace prize and is considered a father of modern UN peacekeeping» }\end{array}$ \\
\hline 2 & $\begin{array}{l}\text { Politibidrag til FN- } \\
\text { fredsoperasjoner }\end{array}$ & «4,000 police officers participated in over 66 peace operations since $1989 »$ \\
\hline 3 & Finansiering & 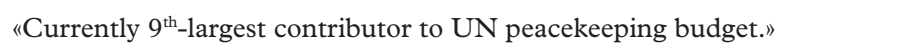 \\
\hline 4 & $\begin{array}{l}\text { Bidrag til FN- } \\
\text { operasjoner, samt ledelse }\end{array}$ & $\begin{array}{l}\text { «Sustain peace, together. More than } 125,000 \text { Canadians have served } \\
\text { abroad in support of UN peacekeeping operations. Our contribution } \\
\text { and commitment to peacekeeping and peacebuilding also manifests itself } \\
\text { through the leadership roles we have taken at the UN» }\end{array}$ \\
\hline
\end{tabular}

5 Brosjyre, Canada, UN security council candidate, 2021-2022 https://www.international.gc.ca/ campaign-campagne/assets/pdfs/unsc-csnu/unsc-csnu-en.pdf 
Her knyttes bidraget til mange ulike aspekter: Til Canada som etablereren av FN-operasjonene, med bidrag økonomisk, ledelsesmessig, og med bidrag både fra politi og det militære. Bildene relatert til det militære i kampanjen, er i motsetning til de to andre kampanjene ikke fokusert på kvinner, men på statsminister Trudeau.

Fredsrelatert tekst er det langt mer av over de 20 sidene. Her har vi måttet velge ut det mest vesentlige:

\begin{tabular}{|c|c|c|}
\hline & Relatert til & Fredsrelatert tekst i Canadas kampanjebrosjyre for SR \\
\hline 1 & Finansiering & «6 ${ }^{\text {th }}-$ largest donor to UN peacebuilding fund» \\
\hline 2 & Fredsbygging & $\begin{array}{l}\text { "As a member of the UN Security Council, Canada will: [...] continue to } \\
\text { strengthen the focus on conflict prevention and peacebuilding. Together, we } \\
\text { can build and sustain peace for the communities we serve.» }\end{array}$ \\
\hline 3 & $\begin{array}{l}\text { Økonomisk vekst og } \\
\text { fred }\end{array}$ & $\begin{array}{l}\text { "As a member of the UN Security Council, Canada will: call attention to the } \\
\text { vital links between sustainable and inclusive economic growth, job creation, } \\
\text { conflict prevention, and peace and security; [...] Together, we can realize the } \\
\text { potential of investment to make a more inclusive, sustainable and peaceful } \\
\text { world.» }\end{array}$ \\
\hline 4 & $\begin{array}{l}\text { Kvinner, fred og } \\
\text { sikkerhet }\end{array}$ & $\begin{array}{l}\text { "As a member of the UN Security Council, Canada will: work toward } \\
\text { increasing the meaningful participation of women in peace negotiations, } \\
\text { mediation and prevention processes, peacekeeping operations and special } \\
\text { political missions» }\end{array}$ \\
\hline
\end{tabular}

Som i de to andre kampanjene er det stort fokus på det fredsrelaterte, og som i de to andre er dette eksplisitt knyttet til likestilling ved flere anledninger. Det er også, mer unikt for Canadas kampanje, knyttet til økonomisk utvikling og vekst. Dette kan sammenlignes med Norges fokus på internasjonal utvikling. For begge land kan dette tolkes som forsøk på å kommunisere et budskap om historiske og fremtidige økonomiske bidrag, rettet mot fattigere land. Siden begge land har forklaringsproblemer vedrørende sine NATO-medlemskap og aktiv deltagelse i ikke-FN konflikter og må vinne støtte fra afrikanske og andre land i Sør - er et fokus på materiell støtte politisk relevant, selv om det gjelder ikke sikkerhet direkte.

\section{Diskusjon}

Som understreket tidligere er differensiering et nøkkelaspekt i branding-aktiviteter. For å lykkes i brandingen, må man altså oppfattes som positivt ulik konkurrentene (Aaker, 2003). Et svært tydelig aspekt når man sammenligner Norge, Irland og Canada, er derimot hvor like de er. Her finner man spenningen i brandingteorien mellom organisasjonens - eller her, nasjonenes - behov for å håndtere press for å være like og press for differensiering (Deephouse, 1999; Wæraas, 2015). Presset for å være like går på et ofte delt syn på legitimitet og underliggende logikk innen relativt like organisasjoner (King \& Whetten, 2008). Samtidig handler branding hovedsakelig om positiv differensiering, noe som kan være vanskelig når nasjonene fremstiller 
seg som relativt like på mange av punktene i kampanjene. Derfor er det interessant hvordan landene understreker ulikhetene som kan relateres til fred og sikkerhet (Irland som ikke-NATO medlem; Norge som et fjernt og ikke-truende land), eller som kan være politisk nyttige (Norge som en stor FN-bidragsgiver; Canada som en stor investor og støttespillere for SDG-ene).

Dette kan videre kompliseres ved å få en nasjons brand til å inneholde ulike og potensielt motstridende elementer, slik diskutert over i henhold til norsk militæraktivisme og fredsaktivisme. Her er stillhetene i Norges masternarrativ i kampanjen interessant - særlig sett i lys av Irlands understreking av manglende militæraktivisme. Militæraktivisme er nevnt av Norge, heller enn bortforklart, men diskuteres ikke i talene eller andre tekster. Masternarrativene i samfunnet, om hvem nordmenn er som et folk og hva som er viktig for det norske, bør ikke oppleves som å stå i strid med nasjonsbrandingen, da denne tjener på å være konsistent. Brandet som fredsnasjon er fleksibelt, og kan være vagt nok til å inkorporere ønskede elementer og samtidig skjule uønskede elementer.

Til syvende og sist fikk Norge en plass i sikkerhetsrådet. Kanskje man kan si at masternarrativet og merkevarebyggingen slo gjennom og viste seg som en effektiv strategi. Samtidig er det sannsynligvis flere andre faktorer som forklarer resultatet særlig Canadas utfordring med å overbevise mange land om at Canadas nyliberale år med store kutt i utviklingsbudsjetter var over. Men at Norge fikk noen flere stemmer enn Irland - som kan skryte av mindre kontroversiell militæraktivisme enn Norge, er kanskje et tegn på at Norge lyktes med å beholde og skape en ønsket forestilling om Norge som en klarert fredsnasjon.

\section{Om forfatterne}

Sigrun Marie Moss er postdoktor i politisk psykologi på psykologisk institutt, Universitetet i Oslo. Hun er tilknyttet UiO:Norden prosjektet Nordic Branding: Politics of Exceptionalism, hvor hun ser på hvorvidt og hvordan de skandinaviske landenes utenriksministerier benytter seg av likestilling i sin nasjonsbranding.

Malcolm Langford er professor i rettsvitenskap på Det juridiske fakultet, Universitet i Oslo. Han leder UiO:Nordens prosjekt Nordic Branding: Politics of Exceptionalism som forsker på hvordan ideen om nordisk eksepsjonalisme ble skapt og hvordan denne brukes.

\section{Referanser}

Aaker, D. (2003). The power of the branded differentiator. MITSloan Management Review, 45(1), 83-87.

Angell, S. I. \& Mordhorst, M. (2015). National reputation management and the competition state. Fournal of Cultural Economy, 8(2), 184-201. https://doi.org/10.1080/17530350.2014.885459

Branner, H. (2013). Denmark between Venus and Mars: How great a change in Danish foreign policy? I N. Hvidt \& H. Mouritzen (Red.), Danish foreign policy yearbook 2013 (s. 134-166). Copenhagen: DIIS.

Browning, C. S. (2007). Branding Nordicity: Models, identity and the decline of exceptionalism. Cooperation and conflict, 42(1), 27-51. doi:10.1177/0010836707073475 


\section{Militeraktivisme brandet som fredsaktivisme?}

Castoriadis, C. (1975). The imaginary institution of society. Cambridge, MA: MIT Press.

Dagbladet. (2003, 12. desember). Farlig forvirring [Leder]. Dagbladet. https://www.dagbladet.no/nyheter/ farlig-forvirring/65933354

Danielsen, H., Larsen, E. \& Owesen, I. W. (2013). Norsk likestillingshistorie 1814-2013. Bergen: Fagbokforlaget.

Deephouse, D. L. (1999). To be different, or to be the same? It's a question (and theory) of strategic balance. Strategic Management fournal, 20(2), 147-166. Hentet fra https://ssrn.com/abstract=2269232

Dicke, R. A., Anson, N., Roughton, P. A. \& Hendrickson, R. C. (2013). NATO burden-sharing in Libya: Understanding the contributions of Norway, Spain and Poland to the War Effort. The Polish Quarterly of International Affairs, 22(4), 29.

Dinnie, K. (2008) Nation branding. Concept, issues, practice. Oxford: Elsevier.

Edström, H., Lunde, N. T. \& Matlary, J. H. (2009). Krigerkultur $i$ en fredsnasjon. Oslo: Abstrakt forlag.

Fan, Y. (2006). Branding the nation: What is being branded? Fournal of Vacation Marketing, 12(1), 5-14. https:// doi.org/10.1177/1356766706056633

Forsvarsdepartementet. (2007). Økt rekruttering av kvinner til Forsvaret (St.meld. nr. 36 (2006-2007). Hentet fra www.regjeringen.no

Græger, N. \& Leira, L. (2005). Norwegian strategic culture after World War Two: From a local to a global perspective. Cooperation and Conflict, 40(1),45-66. https://doi.org/10.1177/0010836705049733

Haaland, T. L. (2007). Participation in peace support operations for small countries: The case of Norway. International Peacekeeping, 14(4), 493-509. https://doi.org/10.1080/13533310701427777

Hammack, P. L. (2008). Narrative and the cultural psychology of identity. Personality and Social Psychology Review, 12(3), 222-247. https://doi.org/10.1177/1088868308316892

Hammack, P. L. (2011). Narrative and the politics of meaning. Narrative Inquiry, 21(2), 311-318. https://doi. org/10.1075/ni.21.2.09ham

Harpviken, K. B. (2011) A peace nation in the war on terror: The Norwegian engagement in Afghanistan. I N. Hynek \& P. Marton (Red.), Statebuilding in Afghanistan: Multinational contributions to reconstruction (s. 157-173). London: Routledge.

Harpviken, K. B. \& Skjelsbæk, I. (2010). Tilslørt fredspolitikk. Nytt Norsk Tidsskrift, 27(4), 379-388. https:// www.idunn.no/nnt/2010/04/art02

Holte, J. F. (2019, 6. mars). Should Norway aspire for a seat at the UN Security Council? [Tale, Civita]. Hentet fra https://www.regjeringen.no/en/aktuelt/unsc_member/id2631475/

Karlsrud, J. \& Osland, K. M. (2016). Between self-interest and solidarity: Norway's return to UN peacekeeping? International Peacekeeping, 23(5), 784-803. https://doi.org/10.1080/13533312.2016.1235096

King, B. G. \& Whetten, D. A. (2008). Rethinking the relationship between reputation and legitimacy: A social actor conceptualization. Corporate Reputation Review, 11(3), 192-207. https://doi.org/10.1057/crr.2008.16.

Langford, M. (2018, 18. august). Norge vingler stadig mer i utenrikspolitikken, så hvorfor skal nettopp vi få plass i FNs sikkerhetsråd? [Debatt]. Aftenposten. https://www.aftenposten.no/meninger/debatt/i/ VRwMG6/norge-vingler-stadig-mer-i-utenrikspolitikken-saa-hvorfor-skal-nettopp

Langford, M. \& Larsen, E. (2018). Branding the Nordics: The politics of exceptionalism. UiO: Norden Working Paper.

Larsen, E., Moss, S. M. \& Skjelsbæk, I. (Red.). (2021). Gender equality and nation branding in the Nordic region. London: Routledge.

Leira, H. (2013). 'Our entire people are natural born friends of peace': The Norwegian foreign policy of peace. Swiss Political Science Review, 19(3), 338-356. https://doi.org/10.1111/spsr.12044

Lynch, S. (2019, 21. september). Glimmers of optimism Ireland can win UN Security Council seat. The Irish Times. https:/www.irishtimes.com/news/world/us/glimmers-of-optimism-ireland-can-win-un-security-councilseat-1.4025259

Matlary, J. H. (2009). Kriger i kamuflasje? Profesjonen og politikken. I H. Edström, N. T. Lunde \& J. H. Matlary (Red.), Krigerkultur i en fredsnasjon (s. 92-130). Oslo: Abstrakt forlag.

Mordhorst, M. (2015). Public diplomacy vs nation branding: The case of Denmark after the cartoon crisis. I Clerc, L., Glover, N. \& Jordan, P. (Red.), Histories of public diplomacy and nation branding in the Nordic and Baltic countries (s. 237-256). Leiden: Brill Nijhoff.

Reicher, S. \& Hopkins, N. (2000). Self and nation. London: Sage.

Rones, N. \& Fasting, K. (2017). Theorizing military masculinities and national identities: The Norwegian experience. I R. Woodward \& C. Duncanson (Red.), The Palgrave international handbook of gender and the military (s. 145-162). London: Palgrave Macmillan.

Skjelsbæk, I. \& Tryggestad,T. L. (2011). Kvinner i det norske forsvaret: Likestilling eller operasjonelt imperativ? Sosiologi i dag, 41(1), 53-75. 
Skjæraasen, M. (2018, 27. april). Så mye koster Norges FN-kampanje. Bistandsaktuelt. https://www. bistandsaktuelt.no/nyheter/2018/sa-mye-koster-kandidaturet-til-sikkerhetsradet/

Skånland, Ø. H. (2009). Norsk utenrikspolitikk i fredens tegn: en diskursanalyse. Internasjonal Politikk, 67(3), 320-348. https://www.idunn.no/ip/2009/03/art19

Skånland, Ø. H. (2010). 'Norway is a peace nation': A discourse analytic reading of the Norwegian peace engagement. Cooperation and conflict, 45(1), 34-54. https://doi.org/10.1177/0010836709347212

Stokke, K. (2010). The soft power of a small state: Discursive constructions and institutional practices of Norway's peace engagement. PCD fournal, 2(1), 137-173. https://doi.org/10.22146/pcd.25724

Stokke, K. (2012). Peace-building as small state foreign policy: Norway's peace engagement in changing international context. International Studies, 49(3-4), 207-231. https://doi.org/10.1177/0020881714532334

Thomassen, C. (2003, 4. september). Forsvarstopp refser Devold. Dagbladet. https://www.dagbladet.no/ nyheter/forsvarstopp-refser-devold/65910957

Utenriksdepartementet. (2018, 25. juni). Speech at the launch of Norway's Security Council campaign [Tale i New York, 22. juni]. Hentet fra https:/www.regjeringen.no/en/aktuelt/launch_campaign/id2605897/

Utenriksdepartementet. (2018a). Norge søker plass i FNs sikkerhetsråd i 2021-2022 [Artikkel]. Hentet fra https:/www.regjeringen.no/no/tema/utenrikssaker/fn/norge_soeker/id2605473/

Utenriksdepartementet. (2020). Hvorfor Norge ønsker en plass i FNs sikkerhetsråd [Artikkel]. Hentet fra https:/www.regjeringen.no/no/tema/utenrikssaker/fn/hvorfor-sr/id2605819/

Van Ham, P. (2001). The rise of the brand state: The postmodern politics of image and reputation. Foreign affairs, 80(5), 2-6. https://doi.org/10.2307/20050245

Van Ham, P. (2008). Place branding: The state of the art. The Annals of the American Academy of Political and Social Science, 616(1), 126-149. https://doi.org/10.1177/0002716207312274

Wæraas, A. (2015). Making a difference: Strategic positioning in municipal reputation building. Local Government Studies, 41(2), 280-300. https://doi.org/10.1080/03003930.2014.930025

\section{Abstract in English \\ Military Activism Branded as Peace Activism? \\ Norway's Campaign for a Seat on the UN Security Council}

In seeking to present itself as a peace nation, how has Norway sought to address its military activism and NATO membership? This tension was apparent in Norway's recent campaign for a seat on the UN Security Council, where the idea of the country as a peace nation stood central. Using nation branding as an analytical framework, we ask how Norway built and sustained this peace narrative and managed the competing narrative of its role in controversial armed conflicts. As a secondary focus, we ask how Norway's two competitors, Ireland and Canada, presented themselves on these two axes of peace and military activism. Ireland posed a particular threat as it is not a NATO member. To explore these questions, we analyse speeches and texts from Norwegian officials regarding the campaign and examine the official campaign material from all three countries. Given that the image of all three countries was generally similar, we find that each country sought to find unique ways to brand themselves as well as countering the few specific advantages of the others. In the case of Norway, we find that during the campaign the country's military activism was downplayed and other themes were foregrounded in the branding, such as gender equality and international development cooperation. This would legitimate the idea of Norway as a peace nation, a reliable partner that all states could trust.

Keywords: Security Council •campaign $\bullet$ nation branding •peace activism • military activism 